\title{
A Mobile-Based Comprehensive Weight Reduction Program for the Workplace (Health-On): Development and Pilot Study
}

Min Kyu Han ${ }^{1}$, MPH, MD; Belong Cho ${ }^{2,3}$, PhD, MD; Hyuktae Kwon ${ }^{3}$, MPH, PhD, MD; Ki Young Son ${ }^{4}$, MPH, PhD, MD; Hyejin Lee ${ }^{5}$, MPH, MD; Joo Kyung Lee ${ }^{6}$, MD; Jinho Park ${ }^{2,3}$, MPH, PhD, MD

\footnotetext{
${ }^{1}$ SK hynix International Medical Center, Wuxi, Jiangsu, China

${ }^{2}$ Department of Family Medicine, Seoul National University College of Medicine, Seoul, Republic of Korea

${ }^{3}$ Department of Family Medicine, Seoul National University Hospital, Seoul, Republic of Korea

${ }^{4}$ Department of Family Medicine, Asan Medical Center, Seoul, Republic of Korea

${ }^{5}$ Department of Family Medicine, Seoul National University Bundang Hospital, Seongnam City, Republic of Korea

${ }^{6}$ Department of Internal Medicine, Korea University Guro Hospital, Seoul, Republic of Korea
}

\section{Corresponding Author:}

Jinho Park, MPH, PhD, MD

Department of Family Medicine

Seoul National University Hospital

101 Daehak-ro Jongno-gu

Seoul, 03080

Republic of Korea

Phone: 82220720865

Email: kkolzzi0@gmail.com

\section{Abstract}

Background: There is a growing interest in mobile technology for obesity management. Despite the known effectiveness of workplace-based weight loss programs, there are few studies on mobile phone-delivered interventions.

Objective: This study aimed to develop and verify an integrated and personalized mobile technology-based weight control program, named Health-On, optimized for workplaces.

Methods: A weight reduction algorithm was developed for calorie prescription, continuous monitoring, periodic feedback and reevaluation, goal resetting, and offline intervention with behavior-changing strategies. A total of 30 obese volunteers (body mass index $\geq 25 \mathrm{~kg} / \mathrm{m}^{2}$ ) participated in the 12-week Health-On pilot program. The primary outcome was weight reduction, and secondary outcomes were improved anthropometric measures, metabolic profiles, and fat computed tomography measures, all assessed preand postintervention.

Results: Health-On incorporated proprietary algorithms and several strategies intended to maximize adherence, using compatible online and offline interventions. The mean weight of 30 participants decreased by $5.8 \%$, and median weight also decreased from $81.3 \mathrm{~kg}$ (interquartile range [IQR] 77.1-87.8) before intervention to $76.6 \mathrm{~kg}$ (IQR 70.8-79.5) after the 12-week intervention period $(P<.001)$. The metabolic profiles and fat measures (blood pressure, glycosylated hemoglobin, total cholesterol, triglyceride, high-density lipoprotein, low-density lipoprotein, alanine aminotransferase, and visceral and subcutaneous adipose tissue; $P<.05$ ) also improved significantly.

Conclusions: In this single-group evaluation of 30 participants before and after the Health-On program, body weight decreased and metabolic profiles and fat measures improved. Follow-up studies are needed to assess effectiveness and long-term adherence.

(JMIR Mhealth Uhealth 2019;7(11):e11158) doi: 10.2196/11158

\section{KEYWORDS}

weight loss programs; smartphone; mobile phone; workplaces; obesity; obesity management 


\section{Introduction}

\section{Background}

Obesity is a major global health problem [1], the cause of increased morbidity and mortality, and significant health care resources are expended on managing and preventing obesity and associated complications [2-5]. Of the options for the treatment of obesity, lifestyle interventions are foundational regardless of augmentation by drug therapy or bariatric surgery. [6,7]. Two principles are central to obesity lifestyle interventions: negative calorie balance and maintenance of it. For physicians, a clinical setting of fragmentary visits and short consultations makes individualized feedback and instruction problematic. For patients, a daily food intake or physical activity diary is intrusive and recollections are unreliable [8].

There is growing interest in lifestyle interventions using smart devices [9], and they can be effective tools to combat obesity, helping to overcome the limitations of current interventions $[10,11]$. They can also be helpful to achieve comprehensive lifestyle modification that is proved to be strongly effective to manage obesity [7,12]. Comprehensive strategy includes group intervention, online or offline interventions on diet and physical activity, frequent monitoring and feedback, and education.

Considering these things, workplace is one of the most optimal places for mobile-based comprehensive lifestyle interventions. Employee numbers will be fairly constant over the intervention period, and employer-provided resources (cafeteria and fitness center), messengers, and periodic health checkup services can

Figure 1. Main pages.
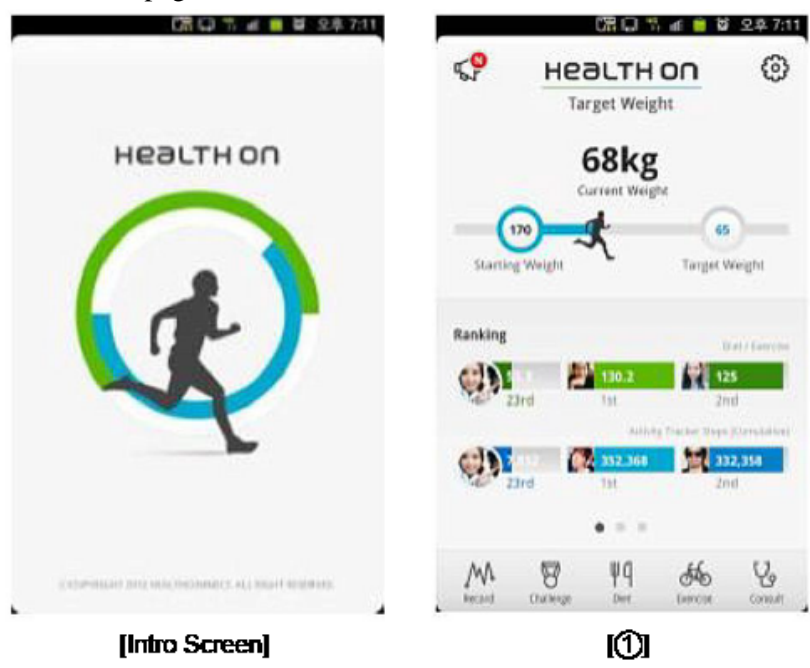

\section{Equation for Calculating an Estimation of Total Energy Expenditure}

To identify the calorie consumption or expenditure negative balance, we must calculate TEE and maintain a TEE greater than calorie intake. TEE is obtained by summating resting metabolic rate (RMR), the thermic effect of activity (TEA), and the thermogenic effect of food (TEF). We chose the predictive Cunningham equation for measuring RMR as it is an accurate formula for estimating RMR using fat-free mass and is close to measured values in Korea [18,19]. For measuring TEA, we used be incorporated into the interventions. The features of mobile health apps (eg, real-time lifestyle monitoring and participant interactivity) can be easily integrated in workplace interventions [13]. In addition, workplace lifestyle interventions are already known to be effective for weight reduction and increased productivity and in reducing financial burden on employees [14-16]. Despite these advantages, mobile-based interventions in practice are rare.

\section{Objectives}

Against this background, we developed a comprehensive mobile app (Health-On) and embarked on a pilot study to verify its workplace feasibility and assess the clinical outcomes before and after the implementation of this program.

\section{Methods}

\section{Development of the Health-On App}

Health-On is a program that combines online devices (mobile app and smart watch) and offline interventional resources (cafeteria, fitness center, and peer support; Figure 1).

Researchers first developed the Health-On mobile phone app using the Android software development kit (SDK r20.0.3) [17].

To accommodate the first principle, negative calorie balance, we developed an equation to calculate total energy expenditure (TEE) and an algorithm to prescribe diet and physical activities. For the second principle, maintenance of negative calorie balance, we created a daily diet or physical activity tracker and applied behavior change strategies.
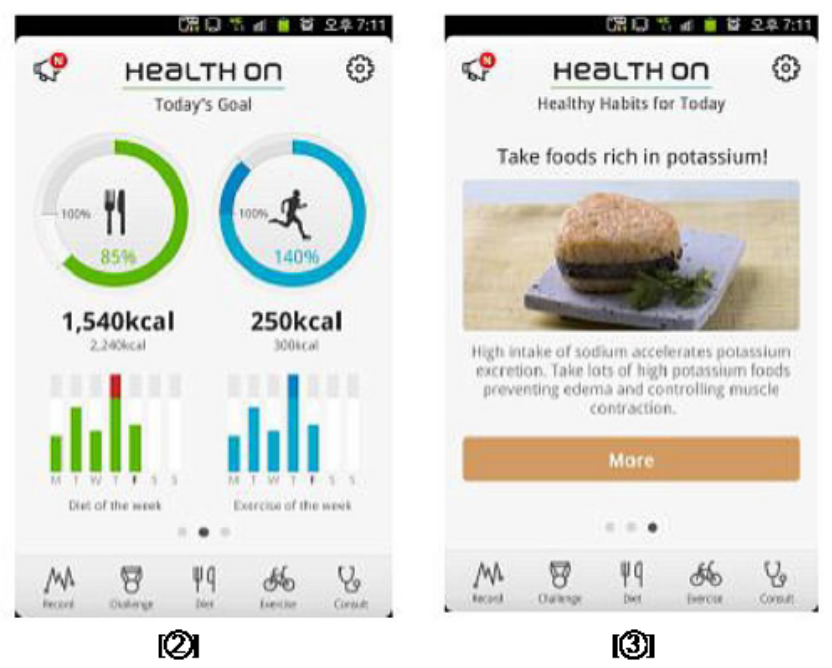

the International Physical Activity Questionnaire Short Form (IPAQ-SF) [20,21]. However, IPAQ-SF does not include calories expended in daily activities, for example, showering or speaking. Thus, we estimated calorie expenditure from these to be $10 \%$ of RMR, on the premise that obese participants are sedentary [22]. TEF was assumed to be $10 \%$ of RMR + TEA [23].

TEE can be expressed as follows: TEE $=$ RMR + TEA $(1)+(2)$ + TEF, where $(1)=\mathrm{kcal}$ consumption from IPAQ-SF and (2)=kcal consumption not included in the IPAQ-SF (eg, walking 
$<10 \mathrm{~min}$ and other daily activities). This equation was used to maintain the negative calorie balance between dietary intake and physical activities.

\section{Diet and Physical Activity Prescription Algorithm}

Following accepted guidelines [7], we set a recommended goal of $7 \%$ baseline body weight loss over 12 weeks, divided into $3.0 \%, 2.5 \%$, and $1.5 \%$ targets for each 4 -week period. We assumed that a $7000 \mathrm{kcal}$ expenditure is needed to lose $1 \mathrm{~kg}$ of body weight [24]. Subjects themselves determined how many negative calories they needed from their control variables, for example, how much they should cut down on eating or how much they should increase physical activity to achieve their weight reduction goals. Then, the algorithm suggested the goals of daily calories from dietary intake necessary to achieve weight loss. These goals and variables were adjusted periodically to reflect weight change during the process. To achieve safe weight reduction, we set quantitative parameters of a minimum of 1200 kcal per day for women and $1500 \mathrm{kcal}$ for men [7].

\section{Convenient Method of Tracking Daily Diet and Physical Activity}

\section{Diet}

Dietary intake could be entered in the app either by inputs on a pre-entered menu or by inputting using the search option.

\section{Pre-Entered Inputs}

We applied various methods to minimize user effort in keying in calories. First, the workplace cafeteria daily menu nutritional data were entered into the app. In addition, menus of restaurants nearby the workplace were entered. Menus that were frequently entered by app users were also pre-entered, thereby automatically appearing in the app.

\section{Input by Search}

We embedded the Canpro4.0 and FanTasy (Food and Nutrition Database System) databases [25,26]. When users consumed foods not on the pre-entered menu, they could search in the app. The typical Korean diet was provided in an easy-to-search select-and-enter list. Meals not on the list could be entered directly by the user.

\section{Physical Activity}

Physical activity could be entered in the app either by automatic input or manually.

\section{Automatic Input}

Health-On enables connectivity with an activity tracker, for example, a smart watch, to measure usual physical activity. The collected data (expended calories and step count) were automatically sent every hour to the app via Bluetooth and made available to users.

\section{Manual Input}

The app enables entry of type, strength, and frequency and duration of aerobic exercise, strength exercise, and common sports, as activity is difficult to measure while using fitness equipment or doing aquatic exercise. This type of user-provided information was calculated and automatically converted into expended calories based on user weight [27].

\section{Behavior Change Strategies}

This program contains several strategies for encouraging behavior change that are effective for weight reduction [28]. We modified these strategies for mobile technology applicability (eg, individualized tailored feedback based on personal life log and ranking). We used resources available in the workplace, for example, the cafeteria and fitness center, to optimize advantages and maximize effectiveness [29].

\section{Health Age}

Health-On can calculate health age from basic health information. We had previously found that a Web-based health risk appraisal (factoring in health age) can be effective for ascertaining health risks and motivating lifestyle modifications [30], and we adjusted this tool for our purposes.

\section{Health Information}

A team of nurses, nutritionists, and exercise trainers devised educational material with diet and physical activity tips. This information was provided in the app daily to improve exercise and dietary habits and ensure effective weight loss. In addition, counseling with a nutritionist and an exercise trainer was made available through social networks.

\section{Feedback on the Life Log}

We developed feedback for self-monitoring and self-reflection on periodic results. Each day, calorie intake was compared with the goal, and goal achievement provided an incentive for further progress. A nutritionist provided feedback on participants' dietary intake records. An exercise supervisor gave feedback based on comparisons between burned calories and exercise targets. Feedback was delivered via a pop-up.

\section{History Query}

With the history query function, users could monitor their health examination results pre- and postprogram, weekly changes in body composition and measurements, and weekly dietary and exercise performance.

\section{Competition}

Good-natured competition, a useful weight loss motivation method, was introduced for promoting Health-On continuous usage. Health-On automatically adds users' friends from contact lists, enabling competition for achievement scores or step counts.

\section{Ranking}

The achievement score was based on the $7.0 \%$ weight loss success or failure compared with the starting weight plus proximity to monthly goals plus dietary input frequency or activity tracker usage.

\section{Step Counts}

The cumulative number of steps over a period, recorded on the activity tracker's pedometer, was used to calculate rankings. 


\section{Health-On Program Pilot Study}

\section{Study Population}

The primary purpose of this study was to verify Health-On's workplace feasibility and assess the clinical outcomes.

In April 2012, an announcement targeting SK telecom workers in a workplace about the recruitment of people with body mass index of more than $25 \mathrm{~kg} / \mathrm{m}^{2}$ [31] who were willing to control diet and exercise for weight loss had been made on the intranet. The Institutional Review Board of Seoul National University Hospital approved this study (IRB No.: H-1204-041-405).

\section{Exclusion Criteria}

We excluded anyone from the recruited members (1) who had answered at least one yes to the questionnaires of Physical Activity Readiness Questionnaire [32], and their eligibility to this study was judged ineligible after counseling, (2) who had answered yes on the eating disorder survey and were judged ineligible for this study after counseling with a doctor, (3) who had systolic blood pressure (SBP) $\geq 160 \mathrm{mmHg}$ or diastolic blood pressure (DBP) $\geq 100 \mathrm{mmHg}$, fasting blood sugar (FBS) $\geq 160 \mathrm{mg} / \mathrm{dl}$, triglyceride $\geq 500 \mathrm{mg} / \mathrm{dl}$, low-density lipoprotein-cholesterol (LDL-C) $\geq 190 \mathrm{mg} / \mathrm{dl}$ and judged ineligible after counseling with a doctor owing to identification of more than one abnormality, (4) who were obese and had received any pharmacological, procedural, or surgical treatment within a month, (5) who had undergone a drastic weight change (more than $10 \%$ of body weight) within a month, (6) who had suffered from or received a procedure because of severe illness such as myocardial infarction, stroke, cancer-related disorders, and hip surgery, (7) who had been suffering from thyroid disease, and (8) who were judged by the researcher as ineligible to participate. A total of 30 people were recruited for this study.

\section{Measurements}

Anthropometric data (height, weight, and percentage of body fat were measured by Inbody 720), fasting blood samples, and computed tomography (CT) scans were collected via questionnaires. Data were collected twice, before and after the 12-week intervention. Participants provided written informed consent, and the Institutional Review Board approved the protocol.

The laboratory tests included alanine aminotransferase (ALT), aspartate aminotransferase, creatinine, lipid profile (total cholesterol, high-density lipoprotein-cholesterol (HDL-C), and triglyceride [TG]), FBS, and baseline glycosylated hemoglobin $\left(\mathrm{HbA}_{1 \mathrm{c}}\right)$. Lipid profiles and blood glucose tests were performed after fasting.

Abdominal adipose tissue mass was estimated using cross-sectional images obtained by a standardized and validated CT technique [33]. Participants were examined in the supine position with a 16-detector row CT scanner (Somatom Sensation 16; Siemens Medical Solutions). A single umbilicus level 5-mm slice image was obtained. The total abdominal adipose tissue area (subcutaneous adipose tissue area plus visceral adipose tissue (VAT) area was calculated using specialized software (Rapidia 2.8; Infinitt) with the attenuation values within a range of -250 to -50 Hounsfield Units. We used VAT $\geq 100 \mathrm{~cm}^{2}$ as the criterion for visceral obesity [34].

\section{Intervention}

On the basis of these health indicators, weight reduction goals and target net kilocalories were individually determined through the Health-On algorithm.

For the first 4 weeks, a 600 to $700 \mathrm{kcal}$ breakfast was provided to create a habit of not skipping breakfast. Participants were encouraged to join Group eXercise once a week at the company gym. Participants were able to check goal achievement by taking Inbody measurements regularly.

A specialist sent review data (LifeStyle Guide) every fortnight, and personal contact was scheduled after the initial health checkup, when checking monthly goals and during a poststudy follow-up.

\section{Outcomes}

The primary outcome of the study was the change in weight of participants before and after the program. We also measured the change in percentage of body fat, lean body mass $(\mathrm{kg})$, waist circumference $(\mathrm{cm})$, serum TG, HDL-C, LDL-C, non-HDL-C, SBP and DBP $(\mathrm{mmHg})$, fasting plasma glucose $(\mathrm{mg} / \mathrm{dL})$, and visceral fat as the secondary outcomes.

\section{Statistics}

The continuous demographic variable and the baseline variable were summarized using descriptive statistics (means with standard deviations and medians with ranges). The categorical demography characteristics were summarized by frequency distribution and percentages. Comparison of the differences between pre- and poststudy outcomes was done with a Wilcoxon signed-rank test.

All analyses were conducted using STATA version 12.1 for Windows (StatCorp), with a $P$ value $<.05$ used to indicate statistically significant differences.

\section{Results}

The interventions discussed in the Methods section are incorporated into the app.

\section{Health-On App (Online Intervention)}

Health-On has 4 theme pages: main, diet, physical activity, and challenge and ranking. Each page allows users to easily see their achievements and to maximize user convenience and app effectiveness with a simple user interface (UI). The theme icons are on the tab menu, making movements between pages smooth and convenient (Figures 2-5). 
Figure 2. Diet pages.

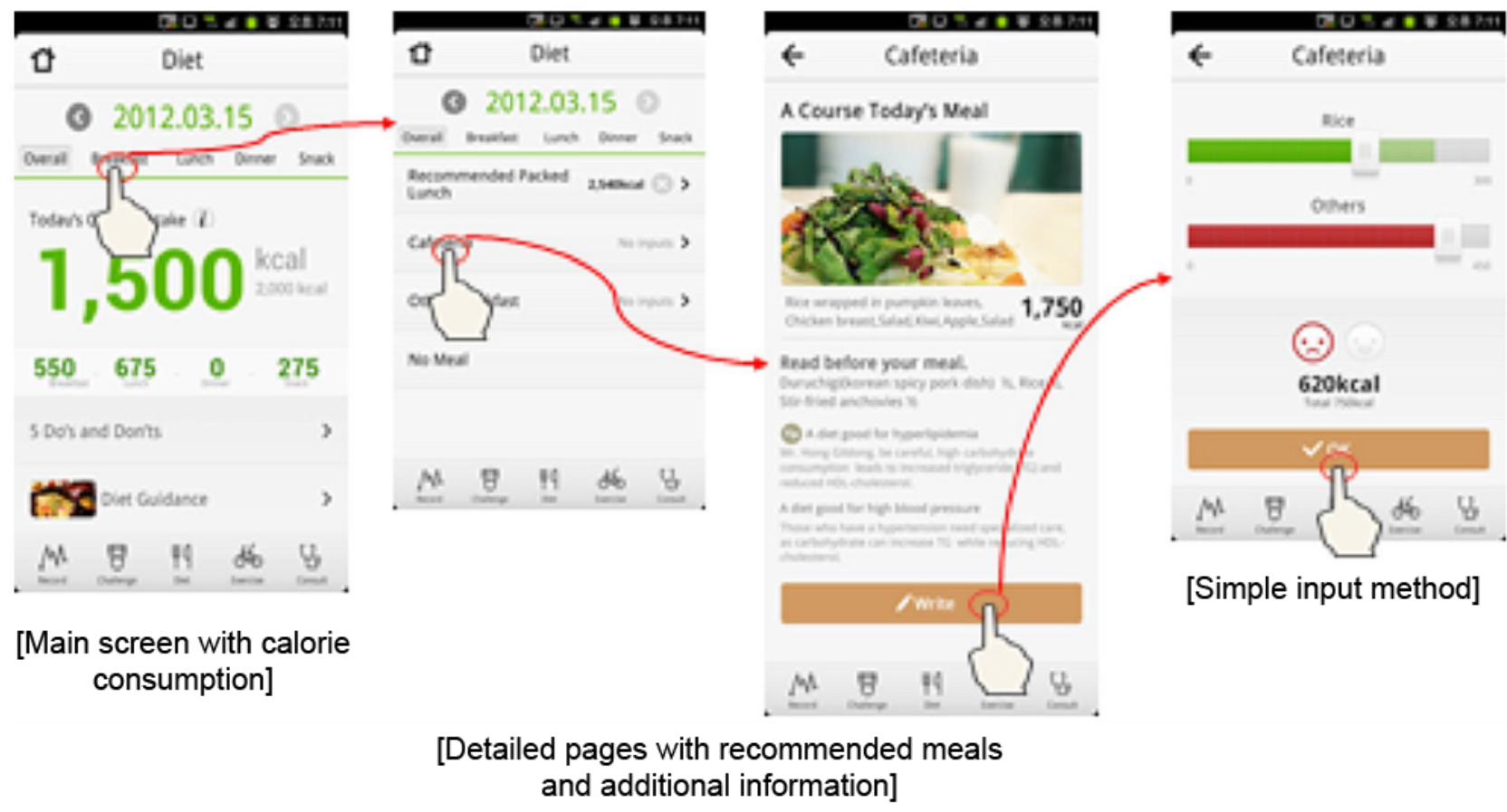

Figure 3. Physical activity pages: activity tracker.
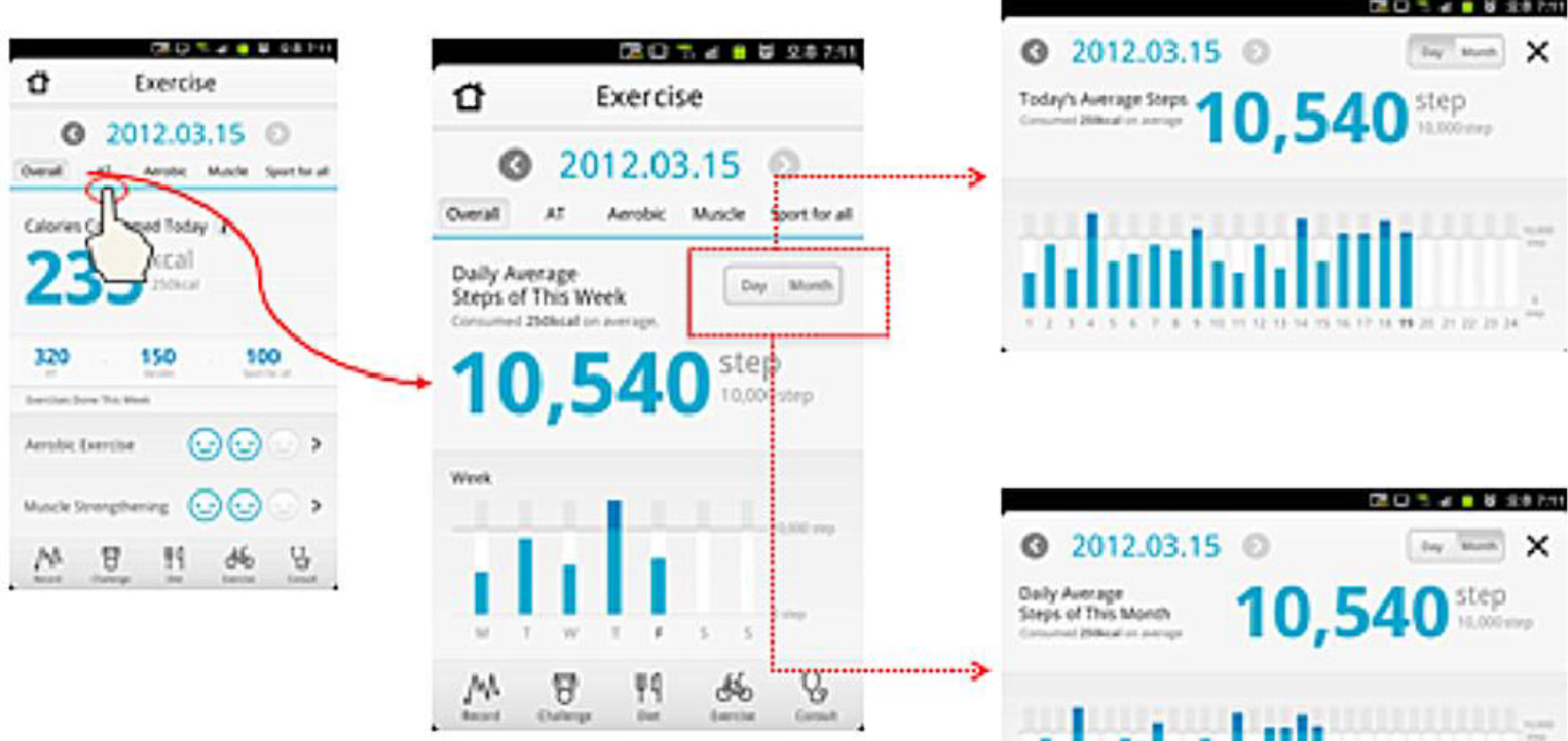

10,540 
Figure 4. Physical activity pages: aerobic exercise.

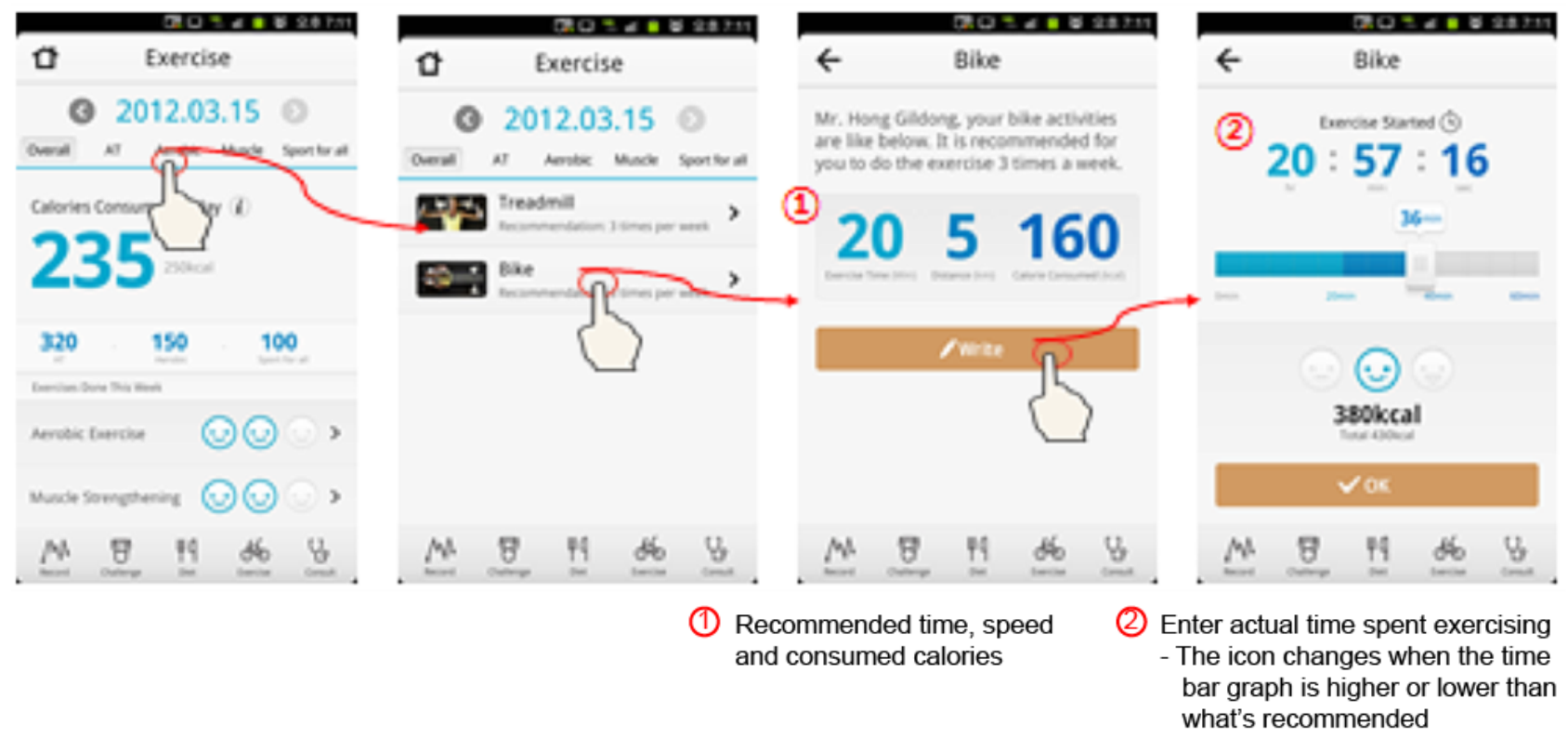

Figure 5. Challenge and ranking pages.

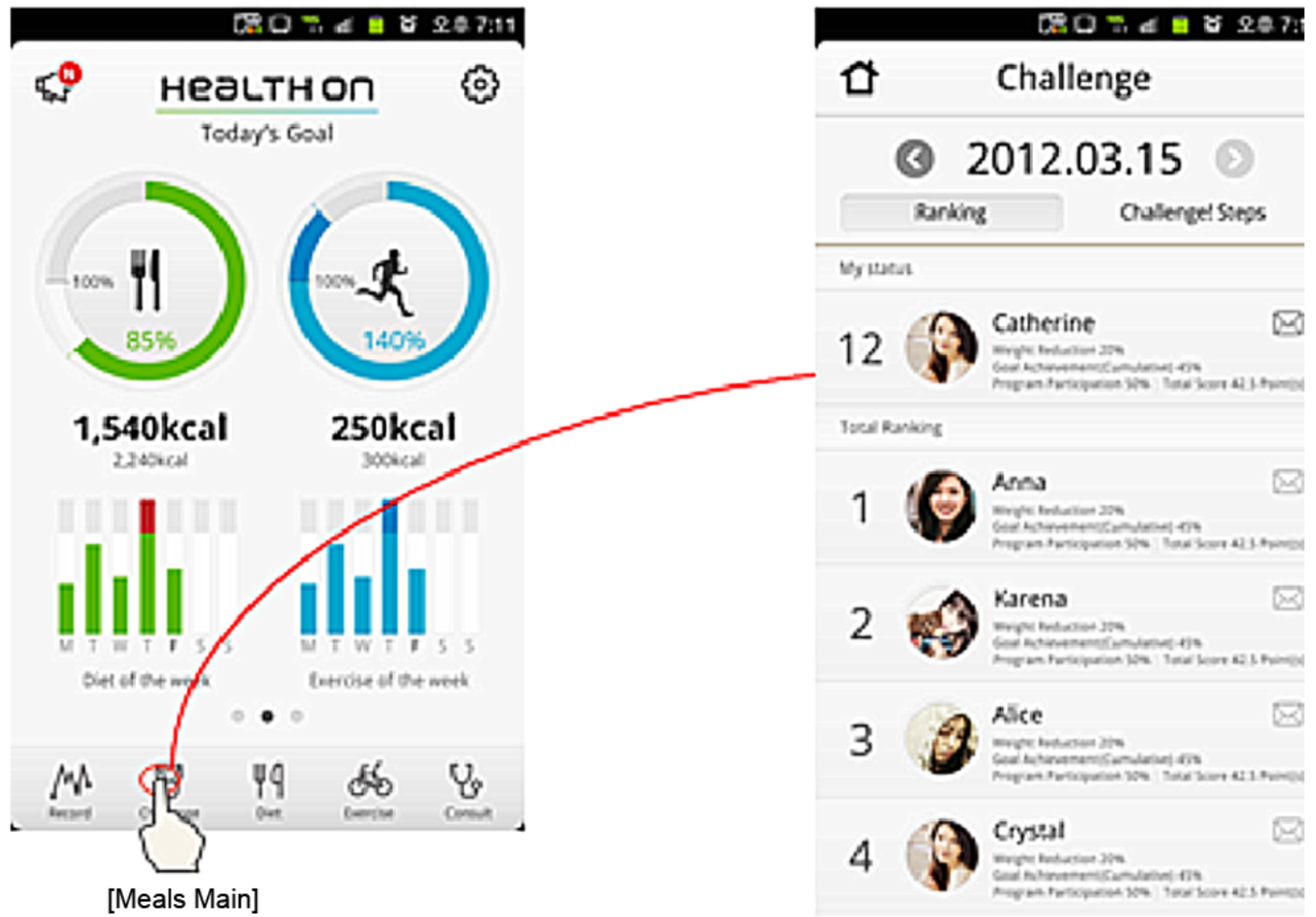

\section{Offline Intervention}

Recommended face-to-face components in internet-delivered weight reduction interventions are included; this increases intervention use and effectiveness [35]. Therefore, the offline intervention for Health-On enables nurses, nutritionists, and exercise trainers to inspect goal achievements and provide periodic feedback.

\section{Pilot Study}

Table 1 shows the baseline characteristics of the participants. Median age was 39 (IQR 35-42) years, and 28 (93.3\%) were male. A total of 9 people (30\%) had an education level above Master's degree, and the rest were college graduates, suggesting a relatively high level of education. 
Table 1. Baseline characteristics of study participants $(n=30)$.

\begin{tabular}{|c|c|}
\hline Variable & Value \\
\hline Age (years), median (IQR) & $39(35-42)$ \\
\hline Male sex, n (\%) & $28.0(93.3)$ \\
\hline \multicolumn{2}{|l|}{ Academic background, n (\%) } \\
\hline Bachelor's degree & $21(70.0)$ \\
\hline Graduate degree or higher & $9(30.0)$ \\
\hline Current smoker, n (\%) & $11(36.7)$ \\
\hline Drinking frequency per week (days), median (IQR) & $1.0(1.0-2.0)$ \\
\hline \multicolumn{2}{|l|}{ Anthropometry, median (IQR) } \\
\hline Height $(\mathrm{cm})$ & $170.4(166.5-173.0)$ \\
\hline Weight (kg) & $81.3(77.1-87.8)$ \\
\hline Waist circumference $(\mathrm{cm})$ & $96.8(93.0-102.5)$ \\
\hline $\mathrm{BMI}^{\mathrm{a}}\left(\mathrm{kg} / \mathrm{m}^{2}\right)$ & $28.0(27.2-30.3)$ \\
\hline \multicolumn{2}{|l|}{ Bioimpedance measurement, median (IQR) } \\
\hline Lean body mass $(\mathrm{kg})$ & $55.4(51.6-58.3)$ \\
\hline Body fat $(\%)$ & $28.2(25.5-30.8)$ \\
\hline \multicolumn{2}{|l|}{ Metabolic profile, median (IQR) } \\
\hline Systolic $\mathrm{BP}^{\mathrm{b}}(\mathrm{mmHg})$ & $128(118-132)$ \\
\hline Diastolic BP (mmHg) & $75(70-81)$ \\
\hline Fasting plasma glucose (mg/dl) & $92(87-98)$ \\
\hline $\mathrm{HbA}_{1 \mathrm{c}}^{\mathrm{c}}(\mathrm{mg} / \mathrm{dl})$ & $5.6(5.5-5.8)$ \\
\hline Total cholesterol (mg/dl) & $205(174-228)$ \\
\hline Triglyceride (mg/dl) & $159(108-214)$ \\
\hline $\mathrm{HDL}^{\mathrm{d}}$ cholesterol $(\mathrm{mg} / \mathrm{dl})$ & $45.5(37.0-53.0)$ \\
\hline $\mathrm{LDL}^{\mathrm{e}}$ cholesterol (mg/dl) & $131.5(97.0-155.0)$ \\
\hline Non-HDL cholesterol (mg/dl) & $154(129-195)$ \\
\hline $\operatorname{AST}^{\mathrm{f}}(\mathrm{IU} / \mathrm{L})$ & $24(19-31)$ \\
\hline $\mathrm{ALT}^{\mathrm{g}}(\mathrm{IU} / \mathrm{L})$ & $30.5(18-59)$ \\
\hline \multicolumn{2}{|l|}{ Fat $\mathrm{CT}^{\mathrm{h}}$, median (IQR) } \\
\hline $\mathrm{CT}$ fat ratio & $0.64(0.50-0.94)$ \\
\hline Visceral fat $\left(\mathrm{mm}^{2}\right)$ & $140.5(110.4-192.9)$ \\
\hline Subcutaneous fat $\left(\mathrm{mm}^{2}\right)$ & $224.3(184.0-292.8)$ \\
\hline
\end{tabular}

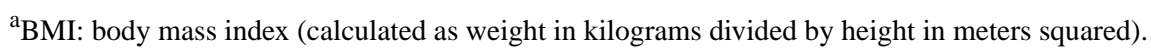

${ }^{\mathrm{b}} \mathrm{BP}$ : blood pressure.

${ }^{\mathrm{c}} \mathrm{HbA}_{1 \mathrm{c}}$ : glycosylated hemoglobin.

${ }^{\mathrm{d}} \mathrm{HDL}$ : high-density lipoprotein.

${ }^{\mathrm{e}} \mathrm{LDL}$ : low-density lipoprotein.

${ }^{\mathrm{f}}$ AST: aspartate aminotransferase.

g ALT: alanine aminotransferase.

${ }^{\mathrm{h}} \mathrm{CT}$ : computed tomography. 
The median of variables was weight $81.3 \mathrm{~kg}$ (IQR 77.1-87.7), abdominal circumference $96.3 \mathrm{~cm}$ (IQR 93.0-102.5), and BMI 28.0 (IQR 27.2-30.3).

Visceral fat and subcutaneous fat were measured by the fat CT, with the median being $140.5 \mathrm{~cm}^{2}$ (IQR 110.4-192.9) and 224.3 $\mathrm{cm}^{2}$ (IQR 184.0-292.8), respectively.
Changes in anthropometric and metabolic profiles between preand postintervention are shown in Table 2 . The mean body weight was decreased by $5.8 \%$. The median of weight, waist circumference, BMI, lean body mass, and body fat percentage reduced significantly, as did most of the metabolic profiles, especially $\mathrm{HbA}_{1 \mathrm{c}}$ and non-HDL-C. The changes in visceral fat and subcutaneous fat were statistically significant.

Table 2. Comparison of outcomes before and after Health-On program $(n=30)$.

\begin{tabular}{|c|c|c|c|c|}
\hline Outcomes & Baseline, median (IQR) & Final, median (IQR) & Difference, median (IQR) & $P$ value \\
\hline \multicolumn{5}{|l|}{ Anthropometric measurement } \\
\hline Weight $(\mathrm{kg})$ & $81.3(77.1$ to 87.8$)$ & $76.6(70.8$ to 79.5$)$ & $-6.2(-8.4$ to 3.9$)$ & $<.001$ \\
\hline Waist circumference $(\mathrm{cm})$ & 96.8 (93.0 to 102.5$)$ & $88(84.5$ to 95.0$)$ & $-9.2(-11$ to 5.5$)$ & $<.001$ \\
\hline $\mathrm{BMI}^{\mathrm{b}}\left(\mathrm{kg} / \mathrm{m}^{2}\right)$ & $28.0(27.2$ to 30.3$)$ & 25.7 (24.6 to 28.0$)$ & $-2.2(-3.4$ to 1.5$)$ & $<.001$ \\
\hline \multicolumn{5}{|l|}{ Bioimpedance measurement } \\
\hline $\operatorname{LBM}^{\mathrm{c}}(\mathrm{kg})$ & 55.4 (51.6 to 58.3$)$ & $54.0(51.2$ to 57.1$)$ & $-1.0(-2.1$ to 0.3$)$ & .003 \\
\hline Body fat $(\%)$ & $28.2(25.5$ to 30.8$)$ & 24.1 (20.9 to 27.6$)$ & $-4.65(-6.5$ to 1.8$)$ & $<.001$ \\
\hline \multicolumn{5}{|l|}{ Metabolic profile } \\
\hline $\mathrm{SBP}^{\mathrm{d}}(\mathrm{mmHg})$ & 128 (118 to 132$)$ & $121(107$ to 127$)$ & $-5.5(-14$ to 2$)$ & .002 \\
\hline $\mathrm{DBP}^{\mathrm{e}}(\mathrm{mmHg})$ & 75 (70 to 81$)$ & $70(63$ to 82$)$ & $-4(-10$ to 2$)$ & .08 \\
\hline Fasting plasma glucose (mg/dl) & $92(87$ to 98$)$ & 90 (86 to 99$)$ & -1.5 ( -8 to 3$)$ & .38 \\
\hline $\mathrm{HbA}_{1 \mathrm{c}}^{\mathrm{f}}(\mathrm{mg} / \mathrm{dl})$ & $5.6(5.5$ to 5.8$)$ & $5.4(5.2$ to 5.6$)$ & $-0.2(-0.4$ to 0.1$)$ & $<.001$ \\
\hline Total cholesterol (mg/dl) & 205 (174 to 228$)$ & $185(158$ to 198$)$ & $-15.5(-31$ to 7$)$ & .001 \\
\hline Triglyceride (mg/dl) & 159 (108 to 214$)$ & $89(57$ to 124$)$ & $-63(-113$ to 25$)$ & $<.001$ \\
\hline $\mathrm{HDL}^{\mathrm{g}}$ cholesterol $(\mathrm{mg} / \mathrm{dl})$ & $45.5(37.0$ to 53.0$)$ & $51(43$ to 62$)$ & $6.5(1$ to 10$)$ & .007 \\
\hline $\mathrm{LDL}^{\mathrm{h}}$ cholesterol $(\mathrm{mg} / \mathrm{dl})$ & 131.5 (97.0 to 155.0$)$ & 107.5 (88 to 125$)$ & -17.5 (-31 to 3$)$ & .001 \\
\hline Non-HDL cholesterol (mg/dl) & 154 (129 to 195$)$ & 126.5 (107 to 145$)$ & $-21.5(-36$ to 11$)$ & $<.001$ \\
\hline $\operatorname{AST}^{\mathrm{i}}(\mathrm{IU} / \mathrm{L})$ & 24 (19 to 31$)$ & 22.5 (17 to 32$)$ & $-1.5(-9$ to 4$)$ & .23 \\
\hline $\operatorname{ALT}^{\mathrm{j}}(\mathrm{IU} / \mathrm{L})$ & 30.5 (18 to 59$)$ & 20.5 (16 to 30$)$ & $-5(-28$ to 1$)$ & .006 \\
\hline \multicolumn{5}{|l|}{ Fat $\mathrm{CT}^{\mathrm{k}}$} \\
\hline $\mathrm{CT}$ fat ratio & $0.64(0.50$ to 0.94$)$ & 0.63 (0.4 to 0.92$)$ & $-0.05(-0.19$ to 0.06$)$ & .09 \\
\hline Visceral fat $\left(\mathrm{cm}^{2}\right)$ & $140.5(110.4$ to 192.9$)$ & $95.6(732.4$ to 133.0$)$ & $-39.4(-60.3$ to 16.3$)$ & $<.001$ \\
\hline Subcutaneous fat $\left(\mathrm{cm}^{2}\right)$ & 224.3 (184.0 to 292.8$)$ & $165.0(117.3$ to 237.9$)$ & $-56.4(-77.0$ to 20.6$)$ & $<.001$ \\
\hline
\end{tabular}

\footnotetext{
${ }^{\mathrm{a}}$ Wilcoxon signed-rank test.

${ }^{\mathrm{c}}$ LBM: lean body mass.

${ }^{\mathrm{d}}$ SBP: systolic blood pressure.

${ }^{\mathrm{e}} \mathrm{DBP}$ : diastolic blood pressure.

${ }^{\mathrm{f}} \mathrm{HbA}_{1 \mathrm{c}}$ : glycosylated hemoglobin.

${ }^{\mathrm{g}} \mathrm{HDL}$ : high-density lipoprotein.

${ }^{\mathrm{h}}$ LDL: low-density lipoprotein.

${ }^{\mathrm{i}} \mathrm{AST}$ : aspartate aminotransferase.

${ }^{\mathrm{j}} \mathrm{ALT}$ : alanine aminotransferase.

${ }^{\mathrm{k}} \mathrm{CT}$ : computed tomography.
}

${ }^{b}$ BMI: Body Mass Index (calculated as weight in kilograms divided by height in meters squared). 


\section{Discussion}

\section{Principal Findings}

The purpose of this study was to develop and verify a comprehensive mobile-based workplace weight reduction program.

Health-On has several strengths compared with other weight reduction apps. Although there are more than 10,000 such apps, a recent review reported that many have insufficient evidence-based content vis-a-vis US government diet and exercise recommendations [35,36]. Health-On incorporates a scientifically evidenced algorithm for estimating negative calorie balance and behavioral strategies established as effective for weight management. In addition, requiring people to complete preprogram health questionnaires, enabled avoidance of participants with health risks. Therefore, Health-On can minimize possible adverse effects, often neglected by other apps.

We created a more convenient method of keying in data. As noted in previous self-monitoring studies, the less intrusive the tool, the higher the rate of adherence [37]. We devised several convenient ways to improve user adherence by collecting data on dietary intake and physical activities. The accuracy and sustainability of keeping a food diary is important; therefore, we attempted to create a user-friendly and nonintrusive UI. Instead of the food diary method, we installed a volume bar for pre-entered diet fields so people can more conveniently record food consumption. This significantly relieves the onerous task of name searching and certainly increases adherence to and sustainability of the program compared with a paper food diary. As for monitoring physical activities, the entry method is more convenient than the paper diary technique that most other apps require. A better approach, such as activity tracking via wearable devices and auto-synchronizing data via Bluetooth, can improve program adherence and compensate for participant self-reporting limitations. Furthermore, physical activities can be quantified and evaluated more accurately.

This program incorporated clinically proven effective behavior change strategies for facilitating weight loss, changes in diet and exercise, and preventing relapse [24,28,37,38]. It is known that if, when deciding the target weight loss, users' diet-exercise preferences are reflected on the target, it will result in greater success [39]. Furthermore, Health-On enables patients to monitor their lifestyles through an everyday life log and allows professionals to provide feedback and educational information. Behavioral changes are promoted through self-monitoring, education, feedback, and competition.

This comprehensive approach combines interventional components that have the strongest effect on obesity (eg, healthy meals) and workplace wellness [15,40]. Most apps do not integrate diet, physical activity, and behavior change strategies $[15,41]$.

Workplace weight management is a highly effective approach to intervention $[3,7,16]$, and Health-On is one of the mobile-based workplace interventions that maximize the advantages and suitability of workplace lifestyle interventions.
Effective population-based weight management is feasible in workplaces, from which supplementary benefits flow, for example, increased productivity, lower absenteeism, and reduced medical costs $[3,7,15,16]$.

In a meta-analytic review, Verweij et al [42] analyzed the effectiveness of workplace interventions targeting physical activity and/or dietary behavior on outcomes. Their study delivered moderate quality evidence that workplace physical activity and dietary behavior interventions significantly reduce body weight ( 9 studies; mean difference $-1.19 \mathrm{~kg}$ [95\% CI -1.64 to -0.74]) [43]. These studies did not use mobile interventions. Stephans et al [43] performed a 3-month randomized controlled trial using a behavior-based mobile phone app. They reported that the difference in weight change between groups was statistically significant (mobile phone group $-1.8 \mathrm{~kg}$ vs Control group $+0.3 \mathrm{~kg} ; P=.03$ ). Direct comparison is difficult owing to research methodological differences, but the weight loss of Health-On is considerable. Changes in anthropometry, bioimpedance measures, metabolic profile, and visceral fat were also significant [42].

During calorie restriction, muscle wasting prevention is important because muscles play an important role in improving metabolic profiles and reducing insulin resistance [44]. Nevertheless, without the simultaneous modification of diet and physical activity, losing weight with a low-calorie diet alone might reduce fat and also fat-free mass [45]. It may superficially seem like a significant reduction in weight but resisting metabolic rate and insulin sensitivity would become lower because of a reduction in muscle mass, thus resulting in the tendency of weight regain [45]. This study was characterized with a body fat reduction $-4.65 \%$ median difference (MD; IQR -6.5 to -1.8 ), and a decrease in muscle mass $1.0 \mathrm{~kg}$ MD (IQR -2.1 to -0.3 ). By preventing muscle loss that could generally occur with a lower calorie diet, it could be concluded that there had been an ideal weight loss achievement with decreased tendency to long-term weight regain.

Interestingly, there was a significant reduction in visceral fat levels despite the short intervention period. Accumulation of VAT is a clinically important marker as it increases insulin resistance to induce metabolic syndrome and heightens cardiovascular risks; therefore, the results of this study demonstrate that Health-On could be effective in managing obesity and lowering the cardiovascular disease risks [46,47].

Through the reduction in obesity rates in workers, as many studies' results previously showed, improved productivity, and reduced absent rates, a reduction in expenses could be expected from the employer [48-50].

\section{Limitations}

This study had several limitations:

1. This study was designed as a pilot test so that direct weight reduction effect of Health-On could be measured. This design is limited in that it does not allow direct comparisons with other forms of treatment. Prospective, randomized trials with appropriate controls are needed.

2. Health-On was developed on an energy balance equation, which was based on scientific evidence such as 
Cunningham's equation, which estimates RMR indirectly [51]. Metabolic rate and calorie expenditure are assumed, not determined through individual differences such as genetic susceptibility to obesity.

3. IPAQ-SF is the desired instrument to measure physical activities, but it considers those within the previous 7 days. There can be differences between daily calorie expenditure calculated from IPAQ-SF and the actual level of physical activity. Although we attempted to compensate for these shortcomings with activity trackers, discrepancies could occur [52].
Despite the short period of this Health-On study, weight reduction was substantial. However, the persistence of weight reduction was unpredictable. Thus, further research for postprogram body weight changes and management is indicated.

\section{Conclusions}

Health-On is a promising workplace intervention tool that can be used in similar environments, for example, universities and the military, with minimal modifications. The results of this study could form a base for designing randomized clinical trials for comparison with conventional weight loss programs. Henceforth, future research should focus on the additional benefits and longitudinal effects of this program.

\section{Acknowledgments}

This study was supported by the Health Connect Co that was created as a joint venture by Seoul National University Hospital and SK Telecom (HC-12-RD-HM-001).

\section{Conflicts of Interest}

None declared.

\section{References}

1. Obesity: preventing and managing the global epidemic. Report of a WHO consultation. World Health Organ Tech Rep Ser 2000;894:i-xii, 1. [Medline: 11234459]

2. $\mathrm{Ng} \mathrm{M}$, Fleming T, Robinson M, Thomson B, Graetz N, Margono C, et al. Global, regional, and national prevalence of overweight and obesity in children and adults during 1980-2013: a systematic analysis for the Global Burden of Disease Study 2013. Lancet 2014 Aug 30;384(9945):766-781 [FREE Full text] [doi: 10.1016/S0140-6736(14)60460-8] [Medline: 24880830]

3. Wang YC, McPherson K, Marsh T, Gortmaker SL, Brown M. Health and economic burden of the projected obesity trends in the USA and the UK. Lancet 2011 Aug 27;378(9793):815-825. [doi: 10.1016/S0140-6736(11)60814-3] [Medline: 21872750]

4. Wilson PW, D'Agostino RB, Sullivan L, Parise H, Kannel WB. Overweight and obesity as determinants of cardiovascular risk: the Framingham experience. Arch Intern Med 2002 Sep 9;162(16):1867-1872. [doi: 10.1001/archinte.162.16.1867] [Medline: 12196085]

5. Specchia ML, Veneziano MA, Cadeddu C, Ferriero AM, Mancuso A, Ianuale C, et al. Economic impact of adult obesity on health systems: a systematic review. Eur J Public Health 2015 Apr;25(2):255-262. [doi: 10.1093/eurpub/cku170] [Medline: 25320051]

6. Knowler WC, Barrett-Connor E, Fowler SE, Hamman RF, Lachin JM, Walker EA, Diabetes Prevention Program Research Group. Reduction in the incidence of type 2 diabetes with lifestyle intervention or metformin. N Engl J Med 2002 Feb 7;346(6):393-403 [FREE Full text] [doi: 10.1056/NEJMoa012512] [Medline: 11832527]

7. Jensen MD, Ryan DH, Apovian CM, Ard JD, Comuzzie AG, Donato KA, American College of Cardiology/American Heart Association Task Force on Practice Guidelines, Obesity Society. 2013 AHA/ACC/TOS guideline for the management of overweight and obesity in adults: a report of the American College of Cardiology/American Heart Association Task Force on Practice Guidelines and The Obesity Society. J Am Coll Cardiol 2014 Jul 1;63(25 Pt B):2985-3023 [FREE Full text] [doi: 10.1016/j.jacc.2013.11.004] [Medline: 24239920]

8. Carter MC, Burley VJ, Nykjaer C, Cade JE. Adherence to a smartphone application for weight loss compared to website and paper diary: pilot randomized controlled trial. J Med Internet Res 2013 Apr 15;15(4):e32 [FREE Full text] [doi: 10.2196/jmir.2283] [Medline: 23587561]

9. Gilmore LA, Duhé AF, Frost EA, Redman LM. The technology boom: a new era in obesity management. J Diabetes Sci Technol 2014 May;8(3):596-608 [FREE Full text] [doi: 10.1177/1932296814525189] [Medline: 24876625]

10. Balk-Møller NC, Poulsen SK, Larsen TM. Effect of a nine-month web- and app-based workplace intervention to promote healthy lifestyle and weight loss for employees in the social welfare and health care sector: a randomized controlled trial. J Med Internet Res 2017 Apr 10;19(4):e108 [FREE Full text] [doi: 10.2196/jmir.6196] [Medline: 28396303]

11. Oh B, Cho B, Han MK, Choi H, Lee MN, Kang H, et al. The effectiveness of mobile phone-based care for weight control in metabolic syndrome patients: randomized controlled trial. JMIR Mhealth Uhealth 2015 Aug 20;3(3):e83 [FREE Full text] [doi: 10.2196/mhealth.4222] [Medline: 26293568] 
12. Beleigoli AM, Andrade AQ, Cançado AG, Paulo MN, Diniz MD, Ribeiro AL. Web-based digital health interventions for weight loss and lifestyle habit changes in overweight and obese adults: systematic review and meta-analysis. J Med Internet Res 2019 Jan 08;21(1):e298 [FREE Full text] [doi: 10.2196/jmir.9609] [Medline: 30622090]

13. Kim J, Oh S, Steinhubl S, Kim S, Bae WK, Han JS, et al. Effectiveness of 6 months of tailored text message reminders for obese male participants in a worksite weight loss program: randomized controlled trial. JMIR Mhealth Uhealth 2015 Feb 3;3(1):e14 [FREE Full text] [doi: 10.2196/mhealth.3949] [Medline: 25648325]

14. Mosa AS, Yoo I, Sheets L. A systematic review of healthcare applications for smartphones. BMC Med Inform Decis Mak 2012 Jul 10;12:67 [FREE Full text] [doi: 10.1186/1472-6947-12-67] [Medline: 22781312]

15. Dobbs R, Sawers C, Thompson F, Manyika J, Woetzel J, Child P, et al. McKinsey \& Company. 2014. How the World Could Better Fight Obesity URL: https://www.mckinsey.com/industries/healthcare-systems-and-services/our-insights/ how-the-world-could-better-fight-obesity [accessed 2019-10-01]

16. Kumanyika SK, Obarzanek E, Stettler N, Bell R, Field AE, Fortmann SP, American Heart Association Council on Epidemiology and Prevention, Interdisciplinary Committee for Prevention. Population-based prevention of obesity: the need for comprehensive promotion of healthful eating, physical activity, and energy balance: a scientific statement from American Heart Association Council on Epidemiology and Prevention, Interdisciplinary Committee for Prevention (formerly the expert panel on population and prevention science). Circulation 2008 Jul 22;118(4):428-464. [doi:

10.1161/CIRCULATIONAHA.108.189702] [Medline: 18591433]

17. Android Developers. Android Studio URL: https://developer.android.com/studio/ [accessed 2018-05-10] [WebCite Cache ID 6zItoM9wl]

18. Lee SH, Kim EK. Accuracy of predictive equations for resting metabolic rates and daily energy expenditures of police officials doing shift work by type of work. Clin Nutr Res 2012 Jul;1(1):66-77 [FREE Full text] [doi: 10.7762/cnr.2012.1.1.66] [Medline: 23429979]

19. Chang UJ, Lee KR. Correlation between measured resting energy expenditure and predicted basal energy expenditure in female college students. J Korean Soc Food Sci Nutr 2005;34(2):196-201 [FREE Full text] [doi: 10.3746/jkfn.2005.34.2.196]

20. Sjostrom M, Ekelund U, Poortvliet E, Hurtig-Wennlöf A, Yngve A. Assessment of physical activity using IPAQ (version 4) and activity monitors (CSA). Meas Phys Educ Exerc Sci 2000;4(4):263-264 [FREE Full text]

21. Oh JY, Yang YJ, Kim BS, Kang JH. Validity and reliability of Korean version of International Physical Activity Questionnaire (IPAQ) short form. J Korean Med Sci 2007 Jul;28(7):532-541 [FREE Full text]

22. Brooks GA, Butte NF, Rand WM, Flatt J, Caballero B. Chronicle of the Institute of Medicine physical activity recommendation: how a physical activity recommendation came to be among dietary recommendations. Am J Clin Nutr 2004 May;79(5):921S-930S. [doi: 10.1093/ajen/79.5.921S] [Medline: 15113740]

23. Willett W. Nutritional Epidemiology. New York, NY: Oxford University Press; 1998.

24. Cowburn G, Hillsdon M, Hankey CR. Obesity management by life-style strategies. Br Med Bull 1997;53(2):389-408. [doi: 10.1093/oxfordjournals.bmb.a011619] [Medline: 9246842]

25. The Korean Nutrition Society. Computer aided nutritional analysis program (CANPRO) version 4 URL: http://www. kns.or.kr/pagegenerater.asp?catalogid=kns2008\&language=ko\&pagecode=sub08 02a [accessed 2012-04-05]

26. Korea Food and Drug Administration. FANTASY (Food And Nutrient daTA SYstem). URL: http://kissna.kfda.go.kr/ [accessed 2012-04-05]

27. Ainsworth BE, Haskell WL, Herrmann SD, Meckes N, Bassett DR, Tudor-Locke C, et al. 2011 Compendium of Physical Activities: a second update of codes and MET values. Med Sci Sports Exerc 2011 Aug;43(8):1575-1581. [doi:

10.1249/MSS.0b013e31821ece12] [Medline: 21681120]

28. Azar KM, Lesser LI, Laing BY, Stephens J, Aurora MS, Burke LE, et al. Mobile applications for weight management: theory-based content analysis. Am J Prev Med 2013 Nov;45(5):583-589. [doi: 10.1016/j.amepre.2013.07.005] [Medline: 24139771]

29. Ritterband LM, Tate DF. The science of internet interventions. Introduction. Ann Behav Med 2009 Aug;38(1):1-3. [doi: 10.1007/s12160-009-9132-5] [Medline: 19816750]

30. Park JH, Kwon H, Oh S, Lee CM, Cho B. Update and validation of a national health risk appraisal tool in Korea. J Public Health (Oxf) 2013 Mar;35(1):107-114. [doi: 10.1093/pubmed/fds061] [Medline: 22888146]

31. Oh SW, Shin S, Yun YH, Yoo T, Huh B. Cut-off point of BMI and obesity-related comorbidities and mortality in middle-aged Koreans. Obes Res 2004 Dec;12(12):2031-2040 [FREE Full text] [doi: 10.1038/oby.2004.254] [Medline: 15687405]

32. Adams R. Revised physical activity readiness questionnaire. Can Fam Physician 1999 Apr;45:992, 995, 1004-992, 995, 1005 [FREE Full text] [Medline: 10216799]

33. Leahey TM, Kumar R, Weinberg BM, Wing RR. Teammates and social influence affect weight loss outcomes in a team-based weight loss competition. Obesity (Silver Spring) 2012 Jul;20(7):1413-1418 [FREE Full text] [doi: 10.1038/oby.2012.18] [Medline: 22310234]

34. Kohl LF, Crutzen R, de Vries NK. Online prevention aimed at lifestyle behaviors: a systematic review of reviews. J Med Internet Res 2013 Jul 16;15(7):e146 [FRE Full text] [doi: 10.2196/jmir.2665] [Medline: 23859884] 
35. The Wall Street Journal. 2011. Software for Shaping Up: Our Picks for Some of the Best Apps to Monitor and Improve Diet and Fitness URL: https://www.wsj.com/articles/SB10001424052748703961104576148732585957902 [accessed 2018-05-10] [WebCite Cache ID 6zIwGxW4J]

36. Breton ER, Fuemmeler BF, Abroms LC. Weight loss-there is an app for that! But does it adhere to evidence-informed practices? Transl Behav Med 2011 Dec;1(4):523-529 [FRE Full text] [doi: 10.1007/s13142-011-0076-5] [Medline: 24073074]

37. Burke LE, Wang J, Sevick MA. Self-monitoring in weight loss: a systematic review of the literature. J Am Diet Assoc 2011 Jan;111(1):92-102 [FREE Full text] [doi: 10.1016/j.jada.2010.10.008] [Medline: 21185970]

38. Artinian NT, Fletcher GF, Mozaffarian D, Kris-Etherton P, van Horn L, Lichtenstein AH, American Heart Association Prevention Committee of the Council on Cardiovascular Nursing. Interventions to promote physical activity and dietary lifestyle changes for cardiovascular risk factor reduction in adults: a scientific statement from the American Heart Association. Circulation 2010 Jul 27;122(4):406-441. [doi: 10.1161/CIR.0b013e3181e8edf1] [Medline: 20625115]

39. Mühlbacher A, Bethge S. Preferences of overweight and obese patients for weight loss programmes: a discrete-choice experiment. Int J Integr Care 2013;13:e034 [FREE Full text] [doi: 10.5334/ijic.1113] [Medline: 24179457]

40. Wing RR, Hill JO. Successful weight loss maintenance. Annu Rev Nutr 2001;21:323-341. [doi: 10.1146/annurev.nutr.21.1.323] [Medline: 11375440 ]

41. Lyons EJ, Lewis ZH, Mayrsohn BG, Rowland JL. Behavior change techniques implemented in electronic lifestyle activity monitors: a systematic content analysis. J Med Internet Res 2014 Aug 15;16(8):e192 [FREE Full text] [doi: 10.2196/jmir.3469] [Medline: 25131661]

42. Verweij LM, Coffeng J, van Mechelen W, Proper KI. Meta-analyses of workplace physical activity and dietary behaviour interventions on weight outcomes. Obes Rev 2011 Jun;12(6):406-429. [doi: 10.1111/j.1467-789X.2010.00765.x] [Medline: 20546142]

43. Stephens JD, Yager AM, Allen J. Smartphone technology and text messaging for weight loss in young adults: a randomized controlled trial. J Cardiovasc Nurs 2017;32(1):39-46 [FREE Full text] [doi: 10.1097/JCN.0000000000000307] [Medline: 26646593]

44. Moon S. Low skeletal muscle mass is associated with insulin resistance, diabetes, and metabolic syndrome in the Korean population: the Korea National Health and Nutrition Examination Survey (KNHANES) 2009-2010. Endocr J 2014;61(1):61-70 [FREE Full text] [doi: 10.1507/endocrj.ej13-0244] [Medline: 24088600]

45. Stiegler P, Cunliffe A. The role of diet and exercise for the maintenance of fat-free mass and resting metabolic rate during weight loss. Sports Med 2006;36(3):239-262. [doi: 10.2165/00007256-200636030-00005] [Medline: 16526835]

46. Lebovitz HE, Banerji MA. Point: visceral adiposity is causally related to insulin resistance. Diabetes Care 2005 Sep;28(9):2322-2325. [doi: 10.2337/diacare.28.9.2322] [Medline: 16123512]

47. Seo D, Niu J. Evaluation of internet-based interventions on waist circumference reduction: a meta-analysis. J Med Internet Res 2015 Jul 21;17(7):e181 [FREE Full text] [doi: 10.2196/jmir.3921] [Medline: 26199208]

48. Naito M, Nakayama T, Okamura T, Miura K, Yanagita M, Fujieda Y, HIPOP-OHP Research Group. Effect of a 4-year workplace-based physical activity intervention program on the blood lipid profiles of participating employees: the high-risk and population strategy for occupational health promotion (HIPOP-OHP) study. Atherosclerosis 2008 Apr;197(2):784-790. [doi: 10.1016/j.atherosclerosis.2007.07.026] [Medline: 17868680]

49. Muto T, Yamauchi K. Evaluation of a multicomponent workplace health promotion program conducted in Japan for improving employees' cardiovascular disease risk factors. Prev Med 2001 Dec;33(6):571-577. [doi: 10.1006/pmed.2001.0923] [Medline: 11716652]

50. Aldana SG, Merrill RM, Price K, Hardy A, Hager R. Financial impact of a comprehensive multisite workplace health promotion program. Prev Med 2005 Feb;40(2):131-137. [doi: 10.1016/j.ypmed.2004.05.008] [Medline: 15533521]

51. Horton ES. Introduction: an overview of the assessment and regulation of energy balance in humans. Am J Clin Nutr 1983 Dec;38(6):972-977. [doi: 10.1093/ajcn/38.6.972a] [Medline: 6650453]

52. Chastin SFM, Culhane B, Dall PM. Comparison of self-reported measure of sitting time (IPAQ) with objective measurement (activPAL). Physiol Meas 2014 Nov;35(11):2319-2328. [doi: 10.1088/0967-3334/35/11/2319] [Medline: 25341050]

\section{Abbreviations}

ALT: alanine aminotransferase

CT: computed tomography

DBP: diastolic blood pressure

FBS: fasting blood sugar

HDL-C: high-density lipoprotein-cholesterol

IPAQ-SF: International Physical Activity Questionnaire Short Form

IQR: interquartile range

LDL-C: low-density lipoprotein-cholesterol

MD: median difference 
RMR: resting metabolic rate

SBP: systolic blood pressure

TEA: thermic effect of activity

TEE: total energy expenditure

TG: triglyceride

UI: user interface

VAT: visceral adipose tissue

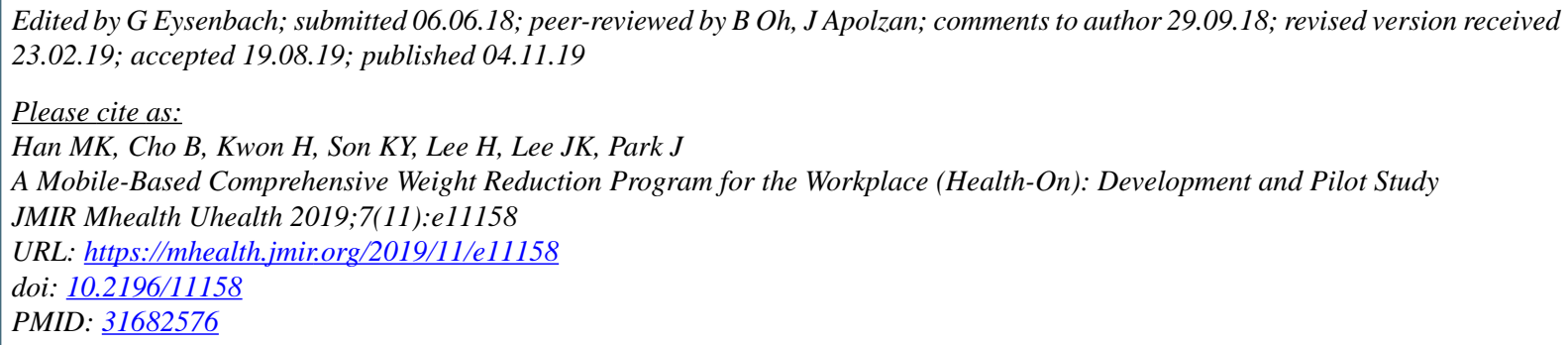

(OMin Kyu Han, Belong Cho, Hyuktae Kwon, Ki Young Son, Hyejin Lee, Joo Kyung Lee, Jinho Park. Originally published in JMIR Mhealth and Uhealth (http://mhealth.jmir.org), 04.11.2019. This is an open-access article distributed under the terms of the Creative Commons Attribution License (https://creativecommons.org/licenses/by/4.0/), which permits unrestricted use, distribution, and reproduction in any medium, provided the original work, first published in JMIR mhealth and uhealth, is properly cited. The complete bibliographic information, a link to the original publication on http://mhealth.jmir.org/, as well as this copyright and license information must be included. 